Preference is given to letters commenting on contributions published recently in the JRSM. They should not exceed 300 words and should be typed double spaced

\section{Delayed diagnosis of slipped upper femoral epiphysis}

The article by Mr Ankarath and colleagues (July 2002 $J R S M^{1}$ ) restates what has been known for at least forty years. The message was necessary since nothing has changed over the years. I agree with the suggested remedynamely, an appropriate X-ray in adolescents with undiagnosed hip or knee pain of more than a week's duration. However, they do not put enough emphasis on the very common presentation with knee pain. Seeing these patients for medicolegal purposes I find that often the doctor first consulted did not examine the hip or observe the gait. Sometimes the knee is X-rayed. Limitation of internal rotation at the hip and walking with the leg in some external rotation are simple warning signs well within the capabilities of a general practitioner or an accident and emergency doctor.

\section{N H Harris}

72 Harley Street, London W1G 7HG, UK

\section{REFERENCE}

1 Ankarath S, Ng ABY, Giannoudis PV, Scott BW. Delay in diagnosis of slipped upper femoral epiphysis. J R Soc Med 2002;95:356-8

\section{Mendel-forgotten or ignored?}

Colin Cowell's letter (July $2002 J_{R S M}^{1}$ ) repeats inter alia the common misconception that Gregor Mendel's work of the 1860s languished unread for 40 years. Not so! As Arno Gustafsson pointed out over 30 years ago ${ }^{2}$, Mendel's work was referred to in the scientific literature a dozen times between its first publication and its 'rediscovery' around 1900. Indeed, as Peter Portin details in his comprehensive study of the development of the concept of the gene ${ }^{3}$, by the beginning of the 19th century it was already recognized by von Niessel and others that Mendel's long-lasting experiments were in no way unknown or hidden but rather were actively put aside on the basis of others' views prevailing. A phenomenon not unknown today.

Ross Kessel

Shute Hill, Malborough, Devon TQ7 3SF, UK

\section{REFERENCES}

2 Gustafsson $\AA$. The life of Gregor Mendel-tragic or not? Hereditas 1969;62:239-59

3 Portin P. Historical development of the concept of the gene. J Med Philosophy 2002;27:250-86

\section{The safety of homeopathic products}

It is regrettable that Professor Kirby's editorial (May 2002 $J R S M^{1}$ ) did not mention a review of this topic conducted and published by us $^{2}$. This was a formal systematic review using prospectively defined inclusion and exclusion criteria and data extraction procedures. It comprised a review of English-language publications and enquiries with manufacturers and regulatory agencies.

Table 1 shows a sample of the data: in therapeutic clinical trials (as opposed to healthy-volunteer homeopathic pathogenetic trials) the incidence of reported adverse effects (AEs) is higher in the verum group than in the placebo group (mean incidence 9.4/6.1).

The conclusions were based on these data and reports of apparent AEs from homeopathic pathogenetic trials (provings) and case reports. The main conclusions were:

- Homeopathic medicines may provoke AEs, but these are generally mild and transient

- There is under-reporting

- There are cases of 'mistaken identity', where herbal and other medicines were described as homeopathic

- The main risks associated with homeopathy are indirect, relating to the prescriber rather than the medicine.

Although strictly speaking outside the remit of the editorial, the last point is particularly important. Not only is it the main risk of homeopathy, but it is a topical issue. Medical practice in the UK is currently essentially unregulated; anybody, irrespective of training or registration, can describe themselves as a homeopath. This is the main preventable source of risk. In their evidence to the House of Lords Select Committee on Complementary and Alternative Medicine ${ }^{3}$, bodies representing non medically qualified acupuncturists and herbalists stated that their professions wished to become statutorily regulated, the Select Committee's report endorsed this view, and the process towards statutory regulation of these professions is now underway.

The non-medical homeopaths, however, indicated that they did not currently wish statutory regulation, despite the view of the Faculty of Homeopathy (doctors and other health professionals practising homeopathy) that homeopathy should be practised only by statutorily registered 


\begin{tabular}{|c|c|c|c|c|}
\hline Trial & Medicine & $\begin{array}{l}\text { Incidence of AEs } \\
\text { with homeopathic } \\
\text { medicines }\end{array}$ & $\begin{array}{l}\text { Incidence of AEs } \\
\text { with placebo }\end{array}$ & Reported AEs \\
\hline Lökken 1995 & Arnica D30 (mostly) & $5 / 24$ & $5 / 24$ & Non-specific complaints (headache, dizziness) \\
\hline Reilly 1994 & Allergen 30C & $1 / 11$ & $2 / 13$ & Aggravation \\
\hline Reilly 1986 & Pollen 30C & $11 / 56$ & $11 / 52^{*}$ & Aggravation \\
\hline Reilly 1985 & Pollen 30C & $1 / 10$ & $7 / 25$ & Aggravation \\
\hline Labrecque 1992 & $\begin{array}{l}\text { Thuj. } \mathrm{CH} 30, \text { Ant-C. } \\
\text { CH7, Nit-Ac. } \mathrm{CH} 7\end{array}$ & $2 / 84$ & $4 / 87$ & Stomach ache, loose stools, pimples and tiredness \\
\hline Attena 1995 & Anas Barbariae $\mathrm{CH} 200$ & $77 / 783$ & $17 / 790^{*}$ & $\begin{array}{l}\text { Aggravation of influenza-like syndrome: myalgia, } \\
\text { low-grade fever, rhinorrhoea, headache, rash, } \\
\text { itching, earache }\end{array}$ \\
\hline Wiesenauer 1995 & Galphimia glauca D4 & $0 / 64$ & $1 / 68$ & Slight nausea in morning \\
\hline Ernst 1990 & Plant complex, $\varnothing$ to D4 & $0 / 31$ & $0 / 30$ & None \\
\hline Jansen 1992 & $\begin{array}{l}\text { Individualized, } 30 \text { to } \\
1000 \mathrm{C}\end{array}$ & $0 / 6$ & $1 / 4$ & Repeated aggravations (placebo) \\
\hline Jacobs 1994 & Individualized, 30C & $0 / 43$ & $0 / 44$ & None \\
\hline De Klerk 1994 & $\begin{array}{l}\text { Individualized D6 to } \\
\text { D200 }\end{array}$ & $12 / 86$ & $13 / 84$ & $\begin{array}{l}\text { Irritability, aggressive behaviour (2), fever, } \\
\text { headache, eczema, vomiting, increased } \\
\text { perspiration (2), rash (2), hyperactivity, ear } \\
\text { discharge, constipation, restlessness, cough, } \\
\text { epistaxis, convulsion, albuminuria }\end{array}$ \\
\hline
\end{tabular}

*Statistically significant

professionals, and that a new profession should be created if necessary.

\section{Peter Fisher}

Homeopathy, Faculty of Homeopathy, 15 Clerkenwell Close,

London EC1R OAA, UK

E-mail: Peter.fisher@uclh.org

\section{Flavio Dantas}

Federal University of São Paulo, Rua Pedro de Toledo 920 São Paulo-SP, 04039-020, Brazil

\section{Hagen Rampes}

West London Mental Health NHS Trust, John Conolly Wing, Uxbridge Road, Southall, Middlesex UB1 3EU, UK

\section{REFERENCES}

1 Kirby BJ. Safety of homeopathic products. J R Soc Med 2002;95:221-2

2 Dantas F, Rampes H. Do homeopathic medicines provoke adverse effects? $\mathrm{Br}$ Hom J 2000;89:S35-38. [Full text available at www.rihh.org.uk/conference (Proceedings 2)]

3 House of Lords Select Committee on Science and Technology. Complementary and Alternative Medicine. London: Stationery Office, 2000

\section{Author's reply}

Dr Fisher and his colleagues' letter, and the article they refer to ${ }^{1}$, are important in drawing attention to areas I shied away from in my editorial — namely, the paucity and quality of data; and the regulation of homeopaths.

Their survey shows how relatively few adverse events have been reported. As they point out, this might be due to under-reporting; or it might reflect the high dilution of homeopathic remedies. I suspect both explanations are correct. The data on which they based their article and letter illustrate the quality of reports pervading much of the published work on homeopathy: they fail to achieve the standards now expected in pharmacovigilance reporting. In order to gain truly sound, objective, data they need to set up a prospective survey, based on pharmacoepidemiological principles, with sufficient statistical power to yield a useful conclusion. Until this has been done the uncertainty I alluded to in my editorial, and as illustrated by their review, will remain.

They raise the question of regulating homeopathy. This opens an important subject extending beyond the scope of a short editorial. The fact remains that there are non-medical homeopaths in practice many of whom have been through training programmes. For those who have not done so, their detailed knowledge about disease is questionable bringing with it the attendant problem that they may sometimes miss a diagnosis where early intervention by a medical practitioner would reduce suffering or even, on occasion, 
save a patient's life. The extent of this problem is a matter of conjecture coloured by a small number of adverse experiences; nonetheless, in our increasingly regulated, consumer-conscious society, there can be no doubt that in this discipline, as in all other therapeutic endeavours, there should be an agreed regulatory framework. What this is to be is something homeopaths and the public will need to work out together, taking note of the strengths and weaknesses of the homeopathy as it is currently practised by medical and non-medical homeopaths.

In conclusion, far from refuting my comments their letter goes a long way in confirming my conclusions; thus I am grateful to Dr Fisher and his colleagues for giving me this opportunity to comment further on the subject.

\section{Brian J Kirby}

3 Pennsylvania Crescent, Exeter EX4 4SF, UK

\section{REFERENCE}

1 Dantas F, Rampes H. Do homeopathic medicines provoke adverse effects? Br Hom J 2000;89:535-8 [Full text available at www.rihh.org.uk/conference (Proceedings 2)]

\section{Unkept outpatient appointments}

Dr Murdock and colleagues (June $2002 J R S M^{1}$ ) think that non-attendance should be addressed by overbooking. I suggest a method that will give an idea of who will or will not attend. Instead of an appointment, a letter is sent to the patient with a date and phone number. The patient is asked to phone on that date and arrange an appointment time. Those who do not phone will not be attending.

Don Genever

5 Rosebery Street, Griffithstown, Pontypool NP4 5HJ, UK

\section{REFERENCE}

1 Murdock A, Rodgers C, Lindsay H, Tan TCK. Why do patients not keep their appointments? Prospective study in a gastroenterology outpatient clinic. J R Soc Med 2002;95:284-6

\section{Decline in autopsy rate}

Organ retention issues have certainly played an important part in the fall in autopsy rate reported by Dr Carr and his colleagues (July $2002 J R S M^{1}$ ). I was disappointed, however, to see no reference to the growing shortage of histopathologists within the NHS and the effect this has undoubtedly had upon postoperative autopsy requesting. The report also expresses concern that only $70 \%$ of autopsy reports were rated satisfactory or better. It may be that the pressure of work upon existing NHS histopathologists has contributed to this result as well. Finally, an issue of more general following the organ retention debate, to minimize the true extent of the supply/demand gap in histopathology. Some would call this judicious demand management in a time of labour scarcity; others would focus more upon the clinical risks and disadvantages demonstrated by Carr and his colleagues.

\section{Roger Dyson}

4 Huskards Back Lane, Fryerning, Ingatestone, Essex CM4 OHR, UK

\section{REFERENCE}

1 Carr NJ, Burke MME, Corbishley CM, Suarez V, McCarthey KP. The autopsy: lessons from the National Confidential Enquiry into Postoperative Deaths. J R Soc Med 2002;95:328-30

\section{Sternoclavicular dislocations}

Mr Kumar and his colleagues (April $2002 J R S M^{1}$ ) should be commended for stressing the potentially fatal consequences if Kirschner wires migrate from the sternoclavicular joint. Sternoclavicular dislocations are uncommon but serious injuries $^{2}$. Closed reduction if attempted within 48 hours of injury is usually successful, although anterior dislocations are frequently unstable ${ }^{3}$. As the risks of open surgical stabilization are high, unstable anterior dislocations postreduction are often best left untreated, whereas unstable posterior dislocations do require intervention because of the proximity of the medial end of the clavicle to the great vessels, oesophagus and trachea ${ }^{3}$.

If operative stabilization of the sternoclavicular joint is required, many techniques have been described, including Kirschner wire fixation, repair of the sternoclavicular and costoclavicular ligaments ${ }^{4}$, reconstruction of the joint with a tendon or fascial graff ${ }^{4}$, and resection of the clavicle medial to the costoclavicular ligament ${ }^{5}$.

Kumar and colleagues state that the most important step in preventing wire migration is to bend the exposed part of the wire after fixation. However, in view of the dangers of Kirschner wire fixation and the excellent outcomes from the other sternoclavicular joint reconstruction procedures mentioned above, it should be emphasized that if joint reconstruction is required, soft tissue techniques should be utilized, and fixation with metal should be avoided altogether.

\section{Paul M Jarrett}

Royal National Orthopaedic Hospital, Brockley Hill, Stanmore, Middlesex HA4 7LP, UK

\section{REFERENCES}

1 Kumar P, Godbole R, Rees GM, Sarkar P. Intrathoracic migration of a Kirschner wire. J R Soc Med 2002;95:198-9

2 Nettles JL, Linscheid RL. Sternoclavicular dislocations. J Trauma 1968; 8:158 
3 Cope R. Dislocations of the sternoclavicular joint. Skeletal Radiol 1992; 22:233-8

4 Eskola A, Vainionpaa S, Vastamaki M, Slatis P, Rokkanen P. Operation for old sternoclavicular dislocation. J Bone Joint Surg Br 1989;71-B:63-5

5 Rockwood CA, Groh GI, Wirth MA, Grassi FA. Resection arthroplasty of the sternoclavicular joint. J Bone Joint Surg Am 1997;79-A:387-93

\section{Animal experiments and the doctor}

Professor Vallance (June $2002 J R S M^{1}$ ) makes the observation that the medical profession has distanced itself from animal research despite being 'the very group that relies on animal experimentation for the treatment it provides' and suggests that doctors join the debate on this issue, as they 'are in a good position to correct misunderstandings and place arguments in a clinically relevant context.' There would, however, appear to be three areas of concern in Vallance's proposition.

First, doctors cannot rely on animal experiments to forecast the effect of drugs on healthy or sick people, far less on people of different sex, age, ethnic origin, or on unborn children. Secondly, the suggestion that doctors are in 'a good position' to correct misunderstandings implies much more than a passing knowledge of animal research. Thirdly, in suggesting that doctors should join the debate, has Vallance considered the reasons that doctors have distanced themselves? Could this be because they are more interested in 'research that may have results that are directly applicable for clinicians and those making public policy' $^{2}$, or for moral, ethical, religious or other reasons? Some doctors may be concerned that expressing views opposing animal research might harm their career prospects - in my own case I only went into print ${ }^{3,4}$ after I had become a consultant.

Medical practitioners should join the debate about the place of animal experimentation in medical research not only for the reasons Vallance puts forward, but also because medical research is failing to stop the rising trend in overall morbidity levels. The most obvious example is diabetes mellitus, which affected about 300000 people in the UK in the 1950 s but which is expected to affect 4 million people by $2010^{5}$. A useful preliminary to the debate might be a survey of doctors' views, to find out why they have distanced themselves from animal experimentation.

\section{Edward J H Moore}

Hillhead Cottage, Inverfarigaig, Inverness IV2 6XR, UK

\section{REFERENCES}

1 Vallance P. Animal experiments and the doctor. J R Soc Med 2002; 95:277

2 Smith R. Animal research: the need for middle ground. BMJ 2001;322 248-9

3 Moore, EJH. Withdrawal of funds for animal experiments at the University of Pennsylvania [Letter]. BMJ 1985;291:605
4 Green R, Moore EJH. Animals under the scalpel - a price we must pay or a cost to our conscience? BMA News Rev August 1991:22-3

5 Dyer O. First cases of type 2 diabetes found in white UK teenagers. BMJ 2002;324:506

\section{Neuromuscular blocking drugs}

The paper by Dr Raghavendra (July $2002 J R S M^{1}$ ) made interesting reading, especially the section on the discovery of curare. In 1982, I had the privilege of visiting Brunei as

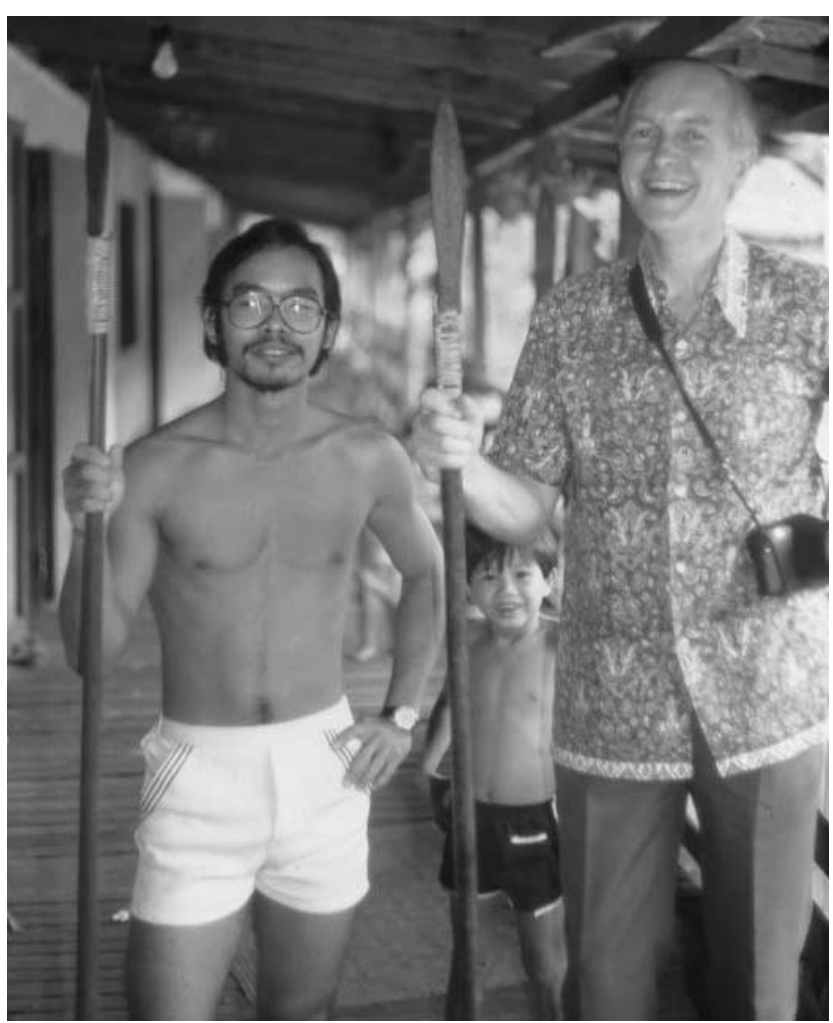

Figure 1 The son of the house with Rex Lawrie who is holding the blow-pipe with spearhead attached

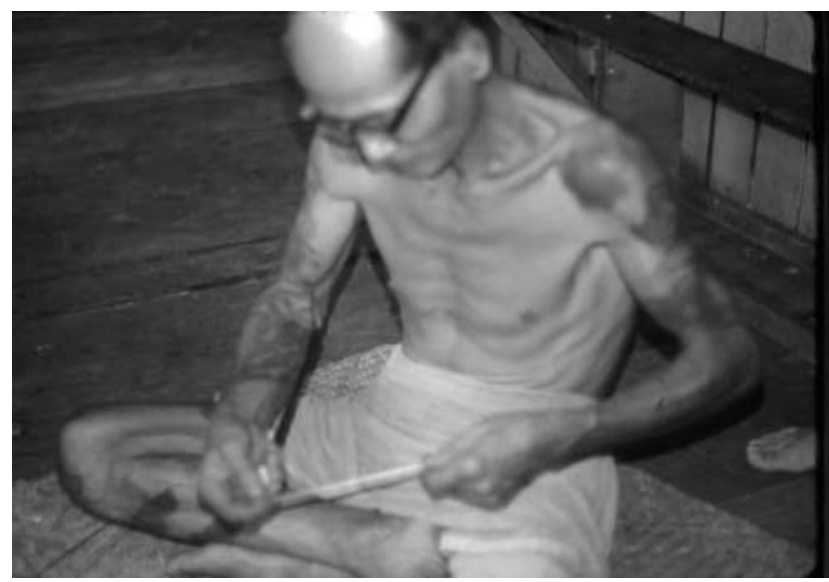

Figure 2 The father of the son of the house mixing the poison used on his darts 
the guest of Mr Rex Lawrie, consultant surgeon (retired). He took me to visit a 'long house' in neighbouring Borneo, where he was acquainted with the son of the owner (Figure 1). I was particularly interested to watch the young man's father, who lived there, mixing some form of poison in a bowl and applying it to the tip of a dart which was used, with his blow-pipe, in hunting game (Figure 2). I never discovered the nature of the poison used. Was it curare? Do any readers of the $J R S M$ have any information about the poison used by the natives of Borneo on their poisoned darts?

\section{J S M Zorab}

Holmray Cottage, Park Street, Iron Acton, Bristol BS37 9UJ, UK

E-mail: Jzorab@compuserve.com

\section{REFERENCE}

1 Raghavendra T. Neuromuscular blocking drugs: discovery and development. J R Soc Med 2002;95:363-7

\section{Waiting in the NHS}

Professor Hamblin (July $2002 J R S M^{1}$ ), writing from the Royal Bournemouth Hospital, lists a number of favourable circumstances that helped Dorset achieve a sustained reduction in waiting times. Improvements in the statistics of waiting lists and waiting times are important politically, and one hopes they will be echoed by the experience of patients.

I have an elderly relative living on her own in Christchurch, Dorset. Towards the end of March this year her GP told her he would refer her for a medical outpatient appointment. In the second week of May she received a letter from the hospital saying that the specialist '. . . has seen your doctor's letter and asked us to place you on the outpatient waiting list. We will write to you four weeks before your appointment is due advising you of the date, time [etc.]'. In the second week of July she received a further letter, stating: '. . . we are now in a position to arrange your appointment. Would you please telephone us at the earliest opportunity to make your Outpatient Appointment.' She telephoned and received an appointment for mid-August.

Does the waiting time start from the referral letter, from the time the consultant had asked to have her placed on the outpatient waiting list, or from the allocation of an appointment? Four and a half months, three months or one month? Her most anxious time was during the first few weeks before she received any response from the hospital at all.

During her waiting time, she spent sixteen days as an inpatient in the same hospital for another matter, during which time she asked whether the medical referral might be dealt with while she was there. This did not happen.

\section{A C Flind}

75 Burnham Green Road, Welwyn, Hertfordshire AL6 ONH, UK

\section{REFERENCE}

1 Hamblin T. Waiting in the NHS. J R Soc Med 2002;95:377

\section{CORRECTION}

'For Merit' - in medicine In this article (June $2002 J_{R S M}^{1}$ ), Box 1 gave an incorrect date for the OM awarded to F Gowland Hopkins. It should have been 1935.

\section{REFERENCE}

1 White H. 'For Merit' - in medicine. J R Soc Med 2002;95:309-10

\section{The elusive art of cannulation}

Why do veins roll on the back of the hand, When at first careful glance so proud do they stand?

The tourniquet on, the blue ropes appear, The Venflon advanced, but the cannula clear.

Why do veins roll with the reg. standing by? But alone on the ward you can bet on first try. Why did He give us the cubital fossa,

But duty demand the dorsum impossa?

Why do veins roll in patients you know? Requiring that plea, 'sorry, just one more go'. So you try contralateral to find something new, While still disbelieving the last one you blew.

Why do veins roll when they're held firm and tight, And you've spied the plump mound that seems to be right, Held fast by two forks and subcut. tissue aplenty?

There's still no flash-back, even with a gauge 20 .

Why do veins roll at the close of the day? When the team needs a break and the scrub nurse can't stay. All eyes focus down on this pitiful student, Who knows to beg help is the course that's most prudent.

'Practice makes perfect', they tell me again, 'For the work of the novice is seldom in vein'.

Mark Howard Guy's, King's and St Thomas' School of Medicine, London, UK 